\title{
Considerations regarding the profile of tourists from Băile Felix - Băile 1 Mai Spa Destination, Romania
}

Authors' Contribution: A Study Design B Data Collection C Statistical Analysis D Data Interpretation E Manuscript Preparation F Literature Search G Funds Collection
Grigore Vasile Herman ${ }^{\mathrm{ACD}}$, Norbert Banto ${ }^{2 \mathrm{AB}}$, Tudor Caciora ${ }^{3 \mathrm{BC}}$, Vasile Grama ${ }^{1 \mathrm{BD}}$, Jakub Trojan ${ }^{4}$ DE, Mihaela Ungureanu'2, 3 BD, Sorin Furdui², 3 BD, Daiana Garai ${ }^{3 \mathrm{BE}}$, Raluca Buhaş ${ }^{5}$, Sorin Buhaş ${ }^{1}$ F

${ }^{1}$ Faculty of Geography, Tourism and Sport, University of Oradea, Oradea, Romania

2 Bihor Destination Management Agency, Oradea, Romania

${ }^{3}$ Doctoral School in Geography, University of Oradea, Oradea, Romania

${ }^{4}$ Tomas Bata University in Zlin, Faculty of Logistics and Crisis Management, Czech Republic

${ }^{5}$ Faculty of Social Sciences, University of Oradea, Oradea, Romania

\section{abstract}

Background: Amid the exponential development of the tourist industry in general and spa tourism in particular that characterises the beginning of the century, the knowledge of tourists' perception regarding the destination image is of utmost importance in order to enhance competitiveness. In this regard, the purpose of this study is to investigate the perception of tourists from Băile Felix - Băile 1 Mai (Romania) about this spa area, in order to establish the profile of the tourist interested in this destination.

Material and methods:

Data was collected by applying a questionnaire (face-to-face technique), structured on eleven questions regarding the degree of knowledge of the destination, the habits of tourist consumption and the perception of the quality-price ratio according to tourist consumption.

Results: Research results indicate a high degree of satisfaction among tourists regarding the destination. They declare themselves satisfied with most services and this determines their quite frequent return and spending an extended period of time at the destination.

Conclusions: As a result, due to the qualitative and quantitative services and tourists' positive perception, Băile Felix - Băile 1 Mai area is one of the most significant spa tourist destinations in Romania.

Key words: tourists' perception, habits of tourist consumption, spa destinations, tourists' profile, tourist destination.

\section{article details}

Article statistics: Word count: 3,335; Tables: 1; Figures: 12; References: 45

Full-text PDF: http://www.balticsportscience.com

Copyright @ Gdansk University of Physical Education and Sport, Poland

Indexation: Celdes, Clarivate Analytics Emerging Sources Citation Index (ESCI), CNKI Scholar (China National Knowledge Infrastructure), CNPIEC, DOAJ, EBSCO - Central \& Eastern European Academic Source, EBSCO - SPORTDiscus, EBSCO Discovery Service, Google Scholar, Index Copernicus, J-Gate, Naviga (Softweco, Primo Central (ExLibris), ProQuest - Family Health, ProQuest - Health \& Medical Complete, ProQuest - Illustrata: Health Sciences, ProQuest Nursing \& Allied Health Source, Summon (Serials Solutions/ProQuest, TDOne (TDNet), Ulrich's Periodicals Directory/ ulrichsweb, WorldCat (OCLC)

Funding: This research was supported by the Bihor Destination Management Agency.

Conflict of interests: Authors have declared that no competing interest exists.

Corresponding author: Sorin Buhaș - Department of Physical Education, Sport and Kinetotherapy, The Faculty of Geography, Tourism and Sport, Oradea, Romania, email:sorin.buhas@gmail.com; phone number: +40 77058113

Open Access License: This is an open access article distributed under the terms of the Creative Commons Attribution-Non-Commercial-NoDerivatives 4.0 International (https://creativecommons.org/licenses/by-nc-nd/4.0/), which permits use, distribution, and reproduction in any medium, provided the original work is properly cited, the use is non-commercial and is otherwise in compliance with the license. 


\section{INTRODUCTION}

Spa tourism is one of the oldest forms of tourism that has been practised for curative reasons since the Roman and the Greek times. Although the way in which it is practised and its perception have changed over time, spa tourism remains one of the most practised forms of tourism worldwide. Wellness tourism is a type of tourism that aims to maintain and improve the physical, mental and spiritual health in an integrated and complex sense [1-3]. Amid the awareness of the majority of the population regarding the importance of health maintenance, this type of tourism has known a considerable increase starting from the 20th century up to now, being estimated at approximately 639 billion dollars in 2017 [4]. The growth and development premises of wellness tourism are also remarkable: the Global Wellness Institute estimates a growth of 7.5\% annually until 2022, when it will reach a record of 919 billion dollars, representing $18 \%$ of the global tourist market. This being known, wellness tourism is undoubtedly a catalyst for the economy at a global, national and local levels.

Within this type of tourism, spa tourism stands out as one of the most important and popular forms [5]. Spa tourism is a human activity performed since time immemorial, with the first documents of practising this form of tourism and its benefits on health coming from the Egyptians, Romans and Greeks [6, 7]. A proof of the long history of spa tourism is the general term SPA, a word whose etymology is found in Latin, meaning "salus per aquam" = health through water. Therefore, the ancient populations, knowing the therapeutic and leisure effects of thermal water, tried to exploit it to maintain and regain health [8]. Even if some aspects related to spa activity have not changed so far, this has undergone considerable mutations over time to meet the constantly evolving consumer demands [9].

The first mutation has in the foreground the degree of accessibility of spa tourism. If in the past this form of tourism was exclusively dedicated to the aristocracy and the elites, nowadays therapeutic tourism is open to all social categories, being an asset in great demand. Furthermore, the limitations related to the high costs of this form of tourism have been removed by the numerous and diverse providers that offer such services, as well as by the fact that a lot of treatments are fully or partially paid by different national health systems [8]. The meaning of the term "spa tourism" and the promoted activities have also altered. Therefore, this is no longer a focus on the treatment of pre-existing conditions, but on a general state of physical, mental and spiritual well-being of the individual, often combined with other types of tourism that target entertainment or broadening knowledge [10]. In a modern sense, health-care tourism is characterized by a double trinomial composed of the objectives "developing-maintaining-improving" that target "body-mind-spirit" [11-13].

\section{MATERIAL AND METHODS}

\section{STUDY AREA}

Due to its unique geothermal resources in Europe, both as volume and territorial diversity and distribution, Romania has been a very important destination for practising spa tourism since ancient times [14, 15]. In this respect, the Roman thermal spa from Herculane was known as one of the oldest spas in the world $[16,17]$ that attracted people from all over the Roman Empire looking for natural ways to heal and get healthy. From the plethora of spa resorts located in Romania, Băile Felix - Băile 1 Mai area is known due to its accommodation capacity and diversity of treatments, being one of the most significant spa resorts at the national level. Located in the Western part of Romania, in Bihor County, being part of Sânmartin commune (Fig. 1), Băile Felix and Băile 1 Mai resorts have a long history of treating various diseases and health problems, the beneficial properties of the thermal water from here being recognized since the 15th and 17th centuries [18-20]. 
This area is recognized mainly for the high temperature of the thermal water (almost $50^{\circ} \mathrm{C}$ ) and for its diversity (oligomineral, calcic, bicarbonate, siliceous and sulphated water), and also for the sapropelic mud wraps, treatments recommended for various diseases and health problems. Besides the therapeutic and preventive effects, geothermal water represents a key factor for tourist motivation, convergent nuclei of health and recreation [21-23]. The curative and recreational tourism, focused on the capitalization of thermo-mineral water, represents one of the most dynamic economic sectors with effects on the sustainable, responsible development of local economy [17, 24-26].

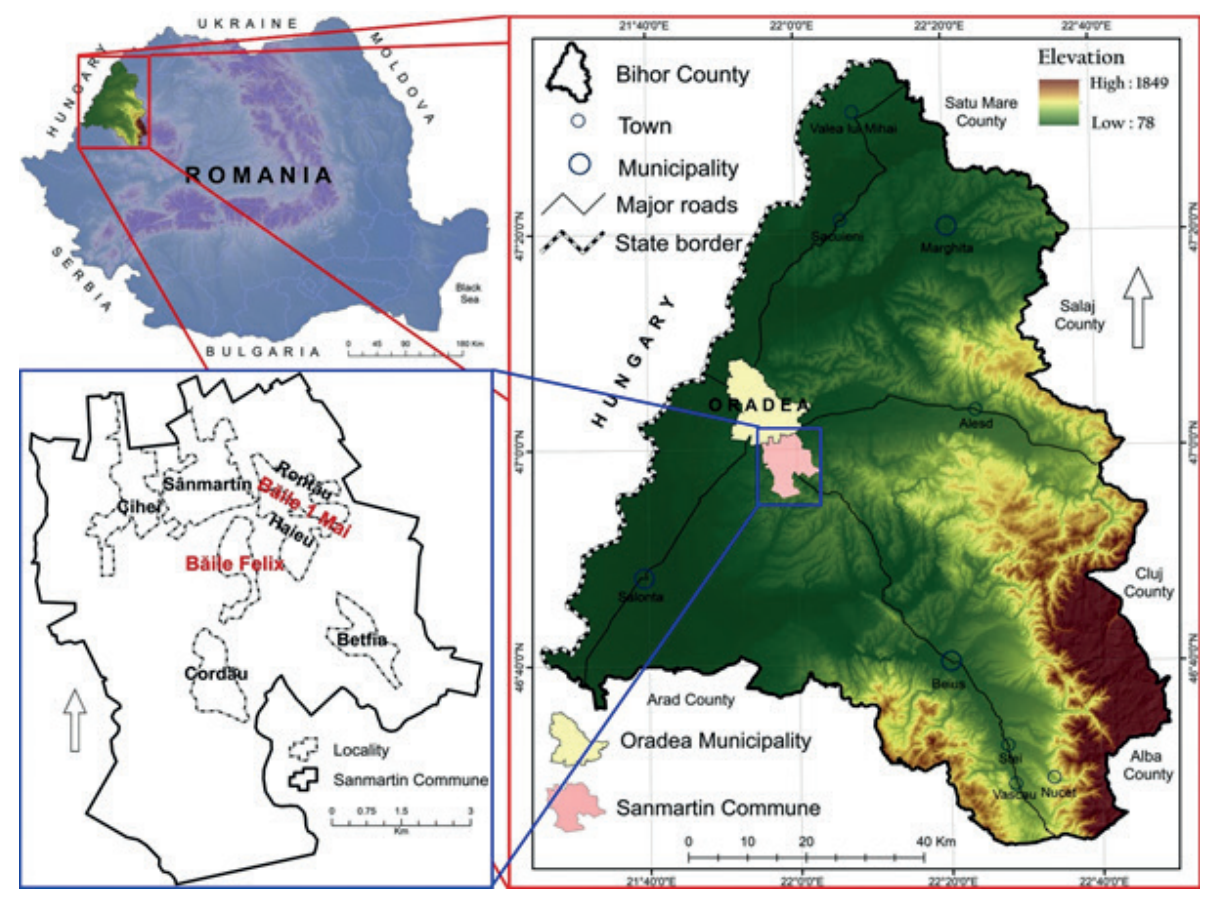

Fig.1. The location of Băile Felix - Băile 1 Mai resorts

In this respect, the proof lies in the number, capacity and high density of the tourism infrastructure elements as well as in the great number of tourists that have chosen this destination. Against this background, the knowledge of the tourists' perception in a highly tourist space with the local economy specialized in tourism is a strategic demand on which the evolution of Băile Felix - Băile 1 Mai destination depends. As a proof, we can notice the growing tendency and the proportion of the companies, employees, turnover and profit in the tourism sector at the level of Băile Felix - Băile 1 Mai tourist system, in 2000-2014 [19].

Taking into consideration the high competitiveness in the tourist sector, the knowledge of the tourists' motivation and perception is a key element in strengthening the image of a tourist destination by anticipating and preventing certain negative aspects, thus influencing the behaviour of tourist consumption, and the decision of visiting and revisiting a given area [27-30].

The aim of the present study is to shape the profile of the tourist, by getting to know his perception regarding the targeted destination. The motivation of the current research is based on the need to intensify tourist activities in the context of the local economic development. Among the key elements based on which the perception of a tourist destination image was formed, special attention was paid to informative-formative data. Based on this, a comparison between the analysed destination and other similar destinations was 
generated as a result of tourist consumption. Our results are necessary premises for tourist destination management, targeting all the stakeholders involved in tourism, both public (local, regional and central) and private (local population, providers of tourist services, tour operators, tourists, etc.).

\section{DATA ANALYSIS}

The necessary data for the present research was collected by applying a questionnaire with eleven thematic questions (regarding the degree of knowledge of the spa destination, the tourists' consumption habits and the perception of the quality-price ratio in the targeted tourist destination) and five socio-demographic items (nationality, gender, age, level of education, foreign languages spoken). Data was collected during May-June 2019, in Băile Felix - Băile 1 Mai spa resorts, using a sociological survey based on a questionnaire (face-to-face) [31-34]. 136 tourists accommodated in seven hotel units (Mureş, Poieniţa, Termal, Lotus, Perla and Internaţional) in the analysed area responded to the questionnaire regarding "The Perception of Băile Felix - Băile 1 Mai spa destination". The sample is a convenience one, due to the fact that subjects were selected considering their willingness to participate in the study.

\section{RESULTS}

To identify and establish the perception of Băile Felix - Băile 1 Mai spa destination among tourists, 136 tourists were questioned, of whom 79 (58\%) were female, 57 (42\%) male, over 18 years old. The majority (92\%) were Romanians, while only $8 \%$ belonged to other ethnical categories. The analysis of age groups highlighted the high proportion of subjects aged between 36 and 65 years old, a fact that shows that this segment of population is interested in prophylactic tourism, while only $0.7 \%$ of them were aged between 18 and 25 . A significant proportion (14\%) was the population over 65 years old, interested both in maintaining and recovering their health. A large part of the participants were educated people, $63.2 \%$ having higher education and speaking many foreign languages, namely English (65.4\%), Hungarian (27\%), German (10.2\%), French (1.4\%) and others (16.9\%) (Table 1).

Table 1. Socio-demographic data of respondents

\begin{tabular}{lcc}
\hline Gender & Male & $57(42 \%)$ \\
& Female & $79(58 \%)$ \\
\hline \multirow{2}{*}{ thnicity } & Romanian & $125(92 \%)$ \\
& Others & $11(8 \%)$ \\
\hline Age & $18-25$ & $1(0.7 \%)$ \\
& $26-35$ & $10(7.4 \%)$ \\
& $36-45$ & $41(30.1 \%)$ \\
& $46-55$ & $35(25.7 \%)$ \\
Level of education & $56-65$ & $30(22.1 \%)$ \\
& $>65$ & $19(14 \%)$ \\
\hline
\end{tabular}




\section{THE DEGREE OF KNOWLEDGE OF BĂILE FELIX - BĂILE 1 MAI SPA DESTINATION}

The creation of a positive image of a tourist destination is a systematic process, a collective effort that benefits from the contribution of each structural element, both natural and anthropic. In this context, knowing the destination represents an essential premise, a fundamental support in shaping the tourists' perception regarding the targeted destination.

A high proportion of respondents (74\%, 100 respondents) declared that they were acquainted with this area, and were not for the first time in Bihor.

Moreover, the degree of knowledge of this destination in Bihor emerges from the analysis of the proportion of the tourists' preferences. Thus, the analysis of respondents' answers to the question "Which are your favourite tourist destinations in Bihor county?" highlighted their preference for Băile Felix - Băile 1 Mai spa area (45.6\%, 62 subjects), Oradea (28.7\%, 39 subjects) and mountain area (20.5\%, 28 subjects) (Fig. 2). This fact shows that tourists from Băile Felix-Băile 1 Mai spa area are also interested in the mountain area $(20.5 \%$ of respondents), a fact that could be capitalized by an intelligent strategy of keeping the tourists in Bihor, by capitalizing on the spa-mountain binomial.

However, from the analysis of the answers offered to the question "Will the promotion of the spa area influence your choice of holiday destination?" a major role played by tourist promotion can be seen; 75.7\% (103 subjects) stated that they were influenced in their decision to spend the holiday in the analysed spa area. From the information sources through which the tourist information got to the tourists, the online (for $32.1 \%$ of the respondents) and the acquaintances'/relatives' opinion (for $29.7 \%$ of the respondents) stood out. The medical prescription, the printed materials and mass-media (radio, TV) promotion materials contributed significantly to the decision of tourist consumption, while at the other end, the promotion of destination at the tourist fairs $(1.9 \%)$ was situated (Fig. 3).

Consequently, the accuracy of tourist information and tourists' experience (relatives/ friends) represent key elements with essential functions in shaping and strengthening the spa destination image [35-37] of Băile Felix-Băile 1 Mai area.

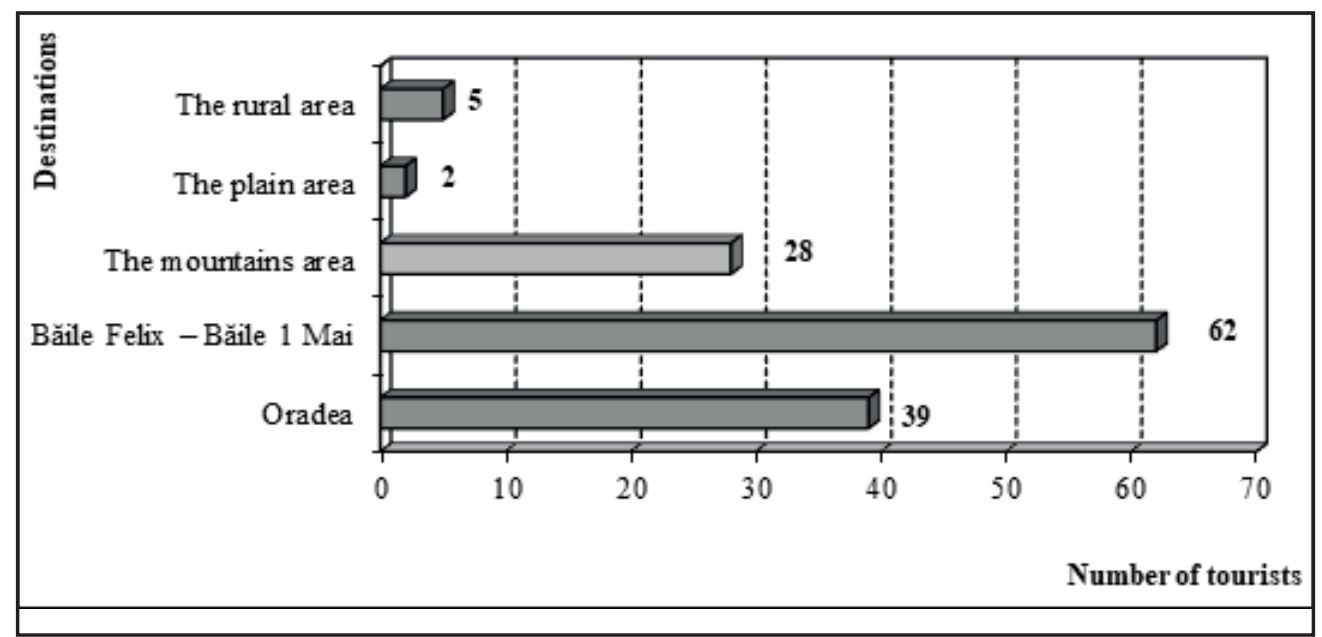

Fig. 2. Subjects` favourite tourist destinations in Bihor county (number of cases) 


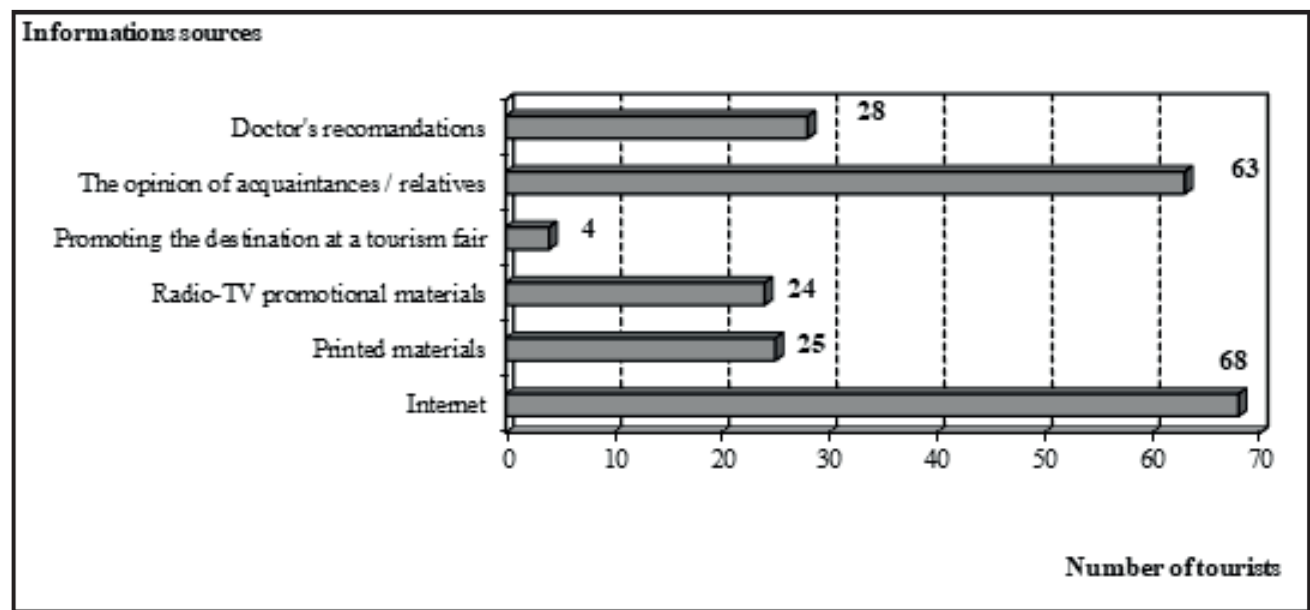

Fig. 3. The information sources regarding Băile Felix - Băile 1 Mai spa area used by the respondents (number of cases)

\section{TOURISTS' CONSUMPTION HABITS}

Knowing tourism consumption habits is a significant subject of interest for the scientific literature in the light of enhancement and expansion of tourism at the global and social level. The scale and dynamic of the substance, energy and information masses involved in tourism require thorough studies to identify tourist consumption habits. The purpose of this approach is that of knowing and meeting the demands of prospective tourists, in accordance with the carrying capacity of the environment corresponding to the targeted destination. Among the essential necessities considered in the present study, the ones related to the type of tourism, duration and frequency of tourist consumption, transportation and accommodation services stand out.

From the analysis of the answers regarding tourists' favourite type of tourism in the spa destination, the preference for recreational and leisure tourism (66.2\%, 90 respondents) emerges, followed by curative and health care tourism (30.9\%, 42 respondents), and cultural-religious tourism (2.9\%, 4 respondents) (Fig. 4).

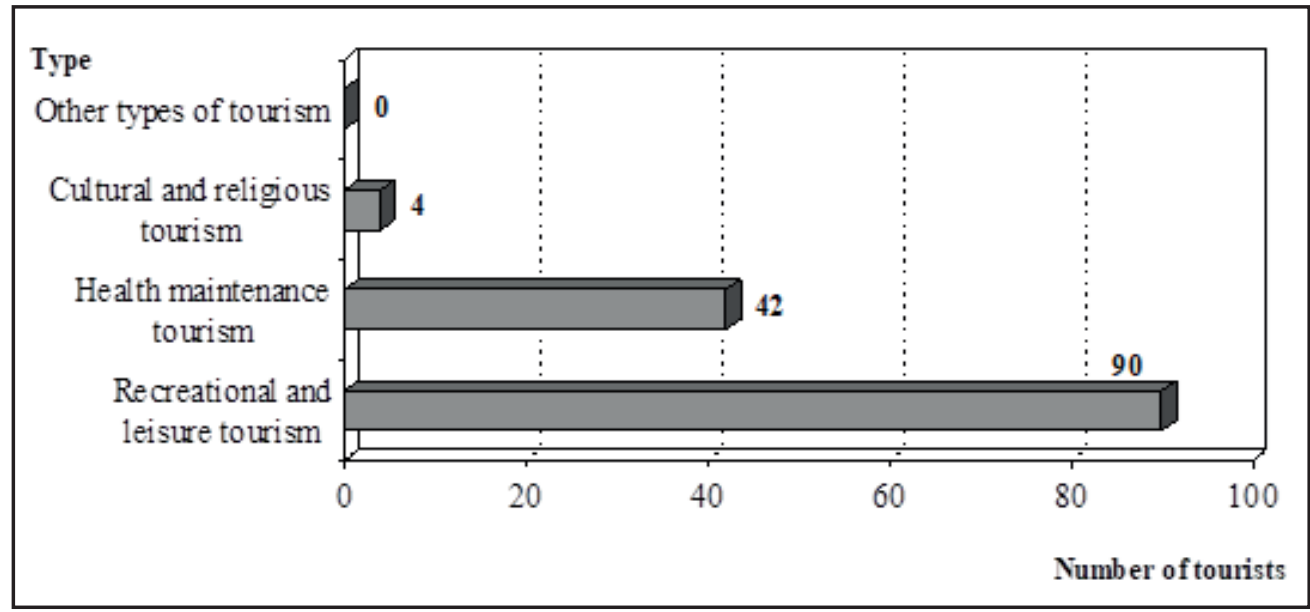

Fig. 4. Tourists' preferences regarding the type of tourism practised in Băile Felix - Băile 1 Mai spa destination (number of cases)

The analysis of the number of nights highlighted that the highest proportion of tourists (60\%, 81 people) spent more than five days at the destination, while the proportion of those who stayed for four and five days was of $26 \%$ (36 people), and 14\% (19 people) for those 
who spent two and three days (Fig. 5). The long period spent at the destination is one of the defining characteristics of the leisure and curative tourism, taking into consideration the fact that the procedures of health maintenance and recovery are time-consuming. But, the fact that approximately $86 \%$ of the interviewed people state that they spent at least 4 days in the destination confirms the quality services and tourists' preferences for this area.

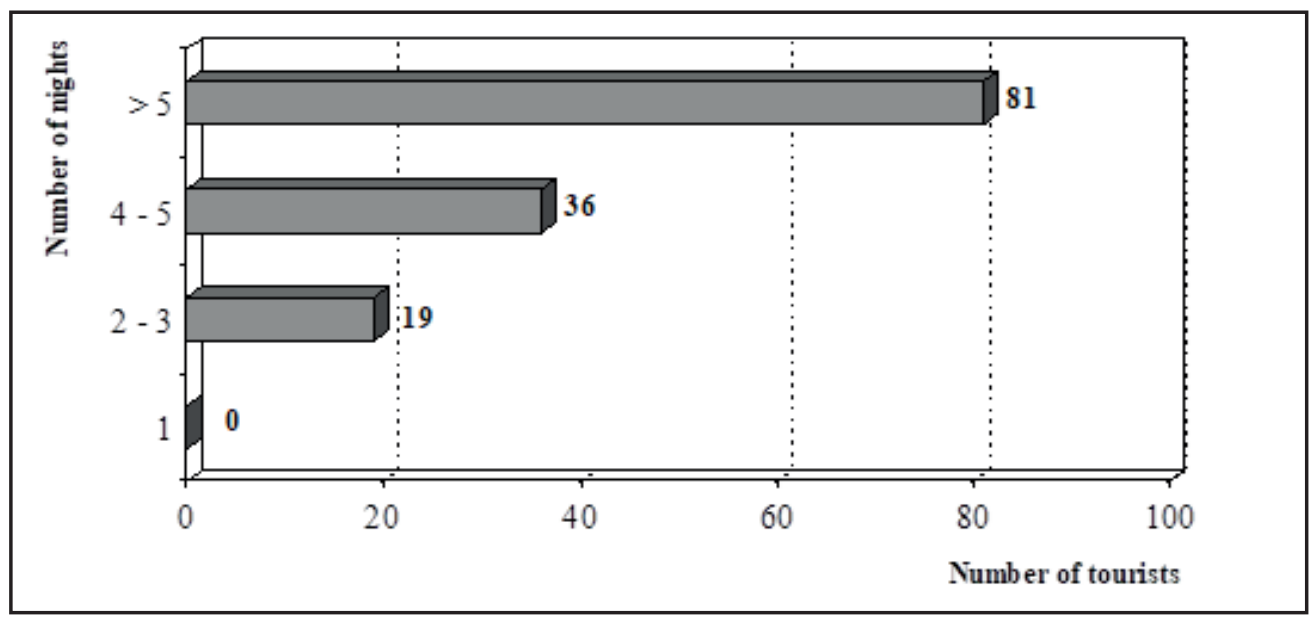

Fig. 5. Number of nights spent in Bihor spa area (number of cases)

The frequency of travels for tourist purposes related to value classes showed the existence of a relatively balanced ratio, as follows: the category of tourists that travel twice a year (29\%, 39 people), followed by those who travel three times per year (27\%, 37 people), more than three times per year (27\%, 37 people) and once (23\%, 23 people) (Fig. 6). These values indicate the tourists' high degree of loyalty to Băile Felix - Băile 1 Mai destination, most of them returning here a few times a year.

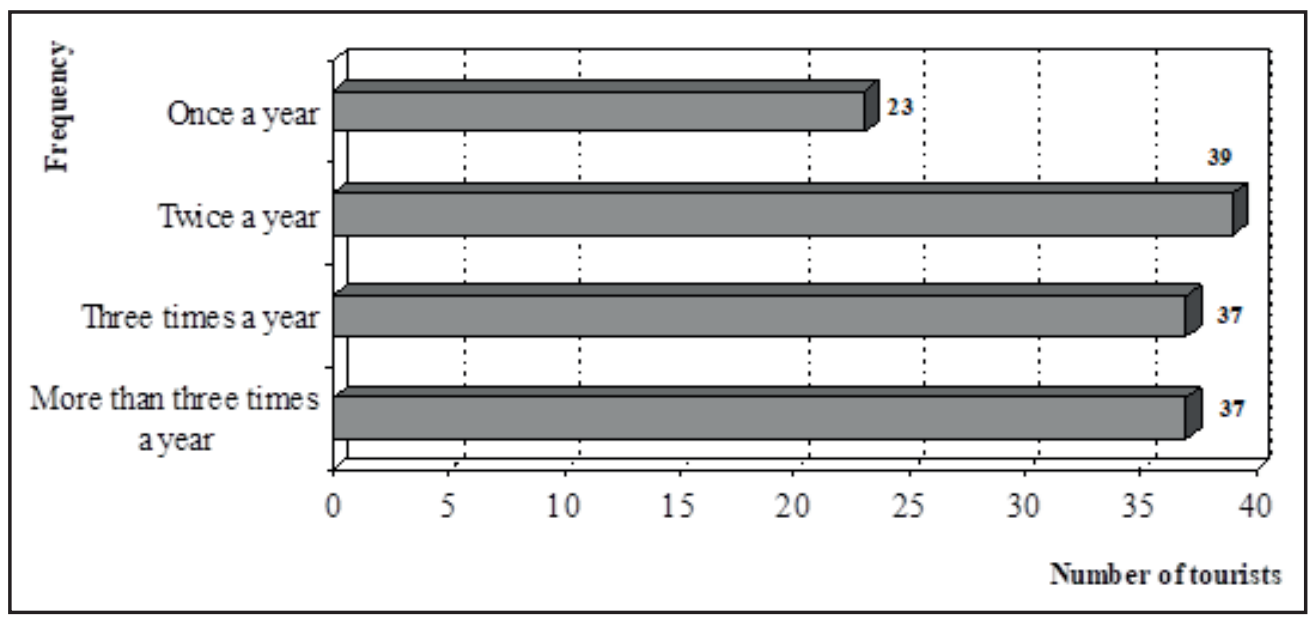

Fig. 6. The frequency of tourists' travels in Bihor spa area (number of cases)

The accessibility of the tourist destinations represents critical factors in the creation of tourists' perception regarding the targeted destinations, which is why people in charge of the management of the access infrastructure have to pay special attention to facilitate the mobility to and from the destination under conditions of maximum safety, speed and comfort. The analysis of tourists' preferences regarding the used means of transport showed the existence of a high proportion in favour of their own cars and coaches (91 people), followed by train (30 people) and plane (15 people) (Fig. 7). The explanations 
for the tourists' preferences lie in many factors, among which the most important are the distance of the journey, the existence and quality of the access infrastructure, the cost of travel, etc.

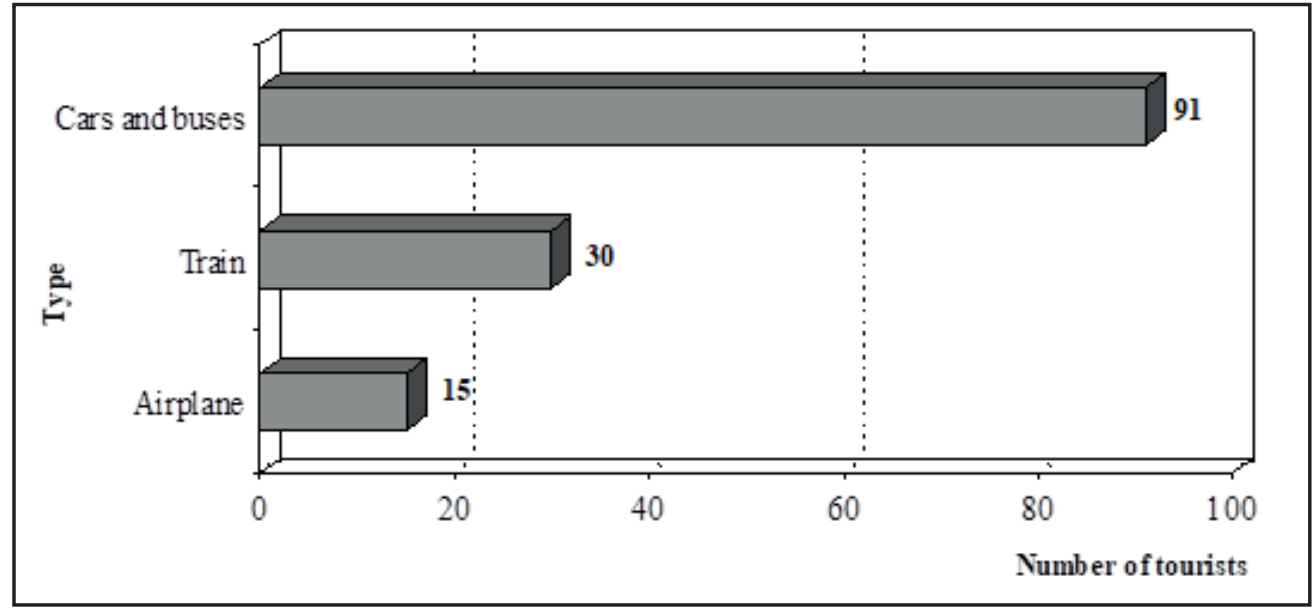

Fig. 7. Tourists' means of transport to Bihor spa area (number of cases)

Regarding the accommodation services, it can be noticed that respondents preferred accommodation in hotels (78\%, 106 people), tourist guesthouses (13\%, 18 people) and other categories of accommodation facililties (9\%, 12 people) (Fig. 8). These accommodation habits are determined by the tourists' desire for comfort, and the fact that most hotels in the targeted area have spas and offer tourists health care treatments, a fact wanted by the majority of tourists who choose Băile Felix - Băile 1 Mai as a holiday destination.

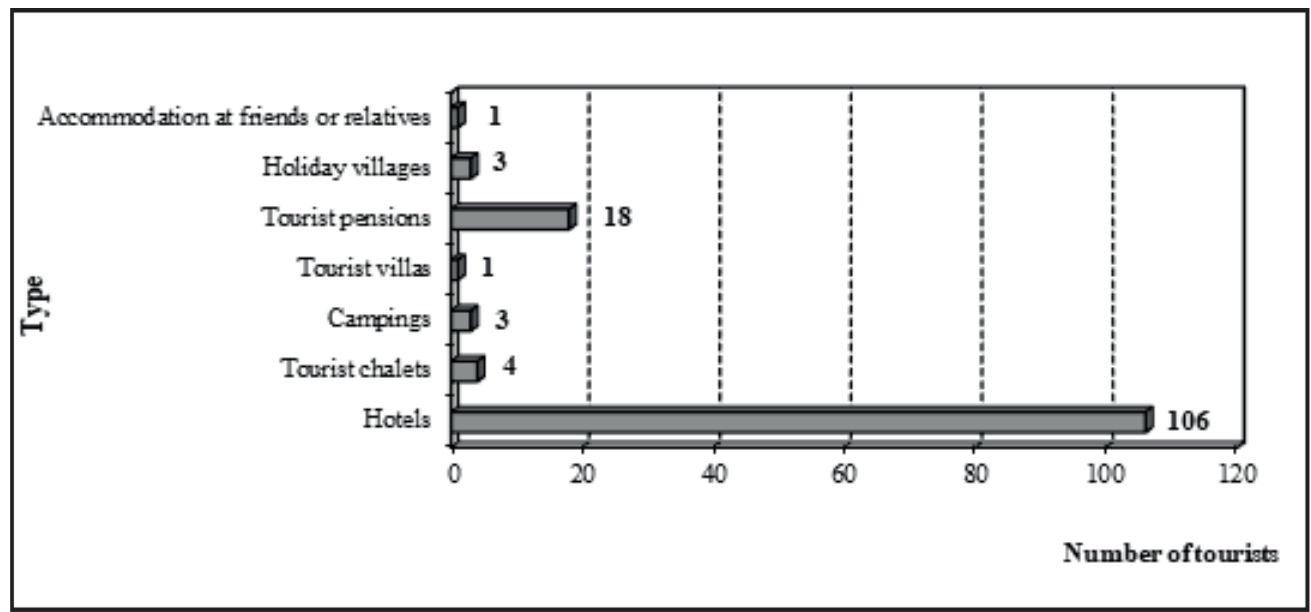

Fig. 8. Tourists' accommodation habits in Bihor spa area (number of cases)

From the above-mentioned information, it is evident that there is a link between tourists' preferences regarding the accommodation in typical categories and the existent accommodation infrastructure. According to the Romanian Ministry of Tourism, in 2019 in Băile Felix - Băile 1 Mai spa destination, the accommodation represented a number of 224 tourist structures with accommodation function (8399 places), distributed in the following proportions: tourist guesthouses (46.7\%), tourist villas (9.8\%), hotels (9.4\%), camping sites (1.3\%) and other categories (33\%) (Fig. 9A), while the existent tourist accommodation capacity in 2019 , indicates the fact that most accommodation places were registered in the hotels (5006 places, 59.6\%), followed by tourist guesthouses (1805 places, $21.5 \%$ ), tourist villas (538 places, $6.4 \%$ ), camping sites (206 places, $2.5 \%$ ), other types of structures (844 places, 10\%) (Fig. 9B). 


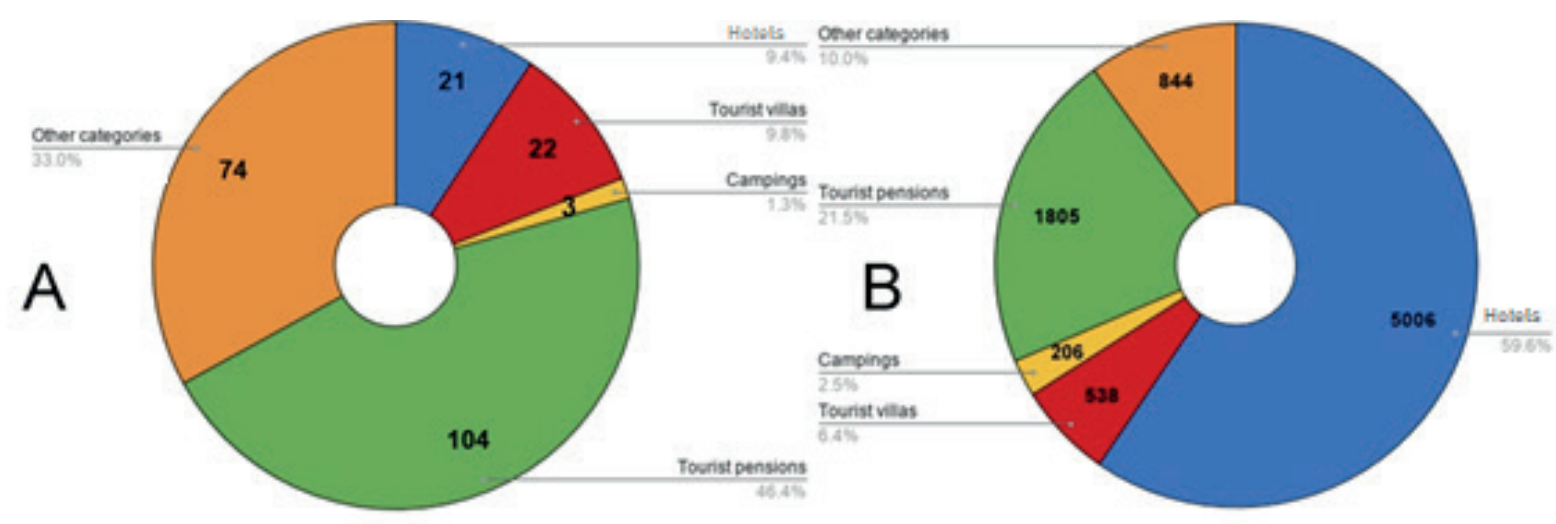

Fig. 9. The proportion of tourist structures with accommodation function in Băile Felix-Băile 1 Mai spa area in 2019; A. Number and proportion of tourist accommodation structures; B. The existent tourist accommodation capacity according to the types of accommodation structures [38]

\section{THE PERCEPTION OF THE QUALITY-PRICE RATIO}

The perception of the quality-price ratio is an essential constant in tourism and in tourist marketing, i.e. formed following the experiences of tourist consumption in various tourist destinations with implications in shaping the tourist destination image.

The analysis of the sums that respondents would be willing to spend on a holiday (three days with two nights per person) in Băile Felix - Băile 1 Mai spa destination showed the existence of four typical categories of tourists: those that can afford to spend sums of 500-1000 RON (32\%, 43 subjects); between 1000 and 2000 RON (31\%, 42 subjects); 2000-5000 RON (23\%, 32 subjects), under 500 RON (11\%, 15 subjects) and over 5000 RON (3\%, 4 subjects) (Fig. 10). We mention the fact that between May and June 2019, when the respondents were consulted, the average net salary in Romania was 3142 lei, respectively 664.2 EURO [39]. 1 Euro $=4.73$ RON [40-42].

Considering the above mentioned information, we can notice the shaping of an austere profile of the tourist willing to spend sums between 500 and 2000 RON. Compared to the level of prices charged in the analysed area, we can say that we are dealing with a relatively balanced to a modest budget.

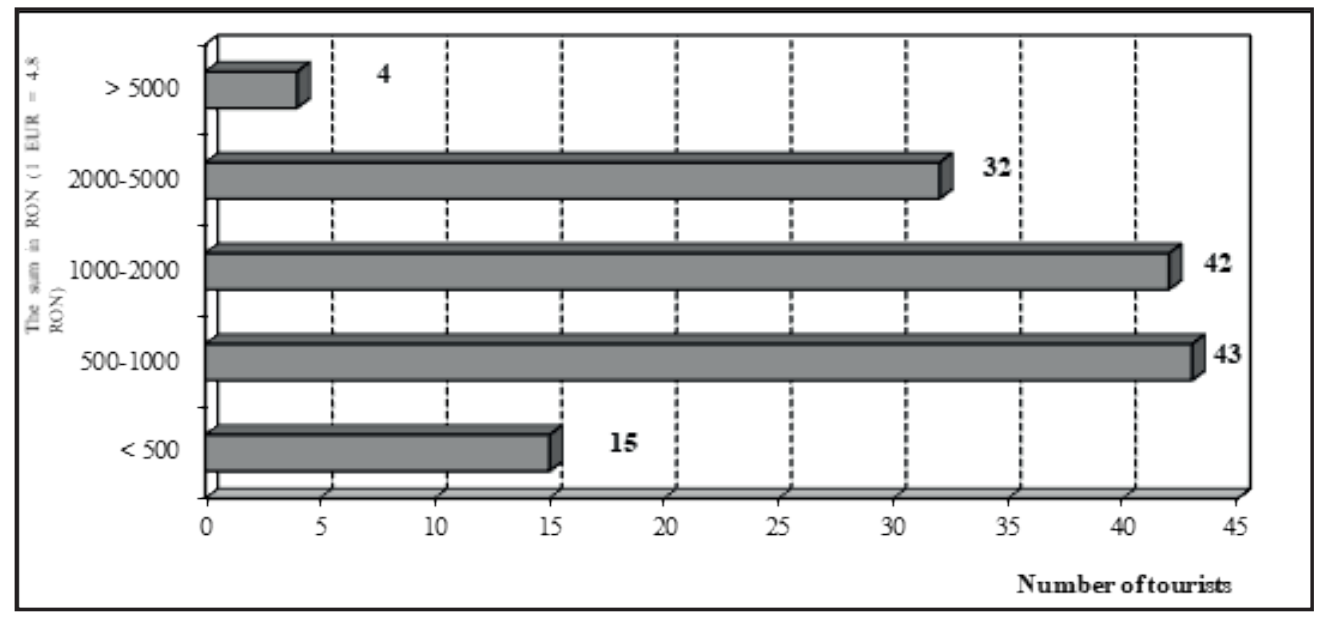

Fig. 10. The value of the sums available to be spent by respondents in one holiday in Bihor spa area (number of cases) 
The analysis of the perception regarding accommodation and food services highlighted the fact that $90 \%$ of tourists stated that they were satisfied with the existent conditions in the accommodation units, only approximately $2 \%$ stating the opposite. Therefore, the majority (50.7\%) assessed the accommodation and food services as very good and good (36\%), while $11 \%$ considered them satisfactory, $1.5 \%$ of poor quality, and only $0.8 \%$ as very poor (Fig. 11 ).

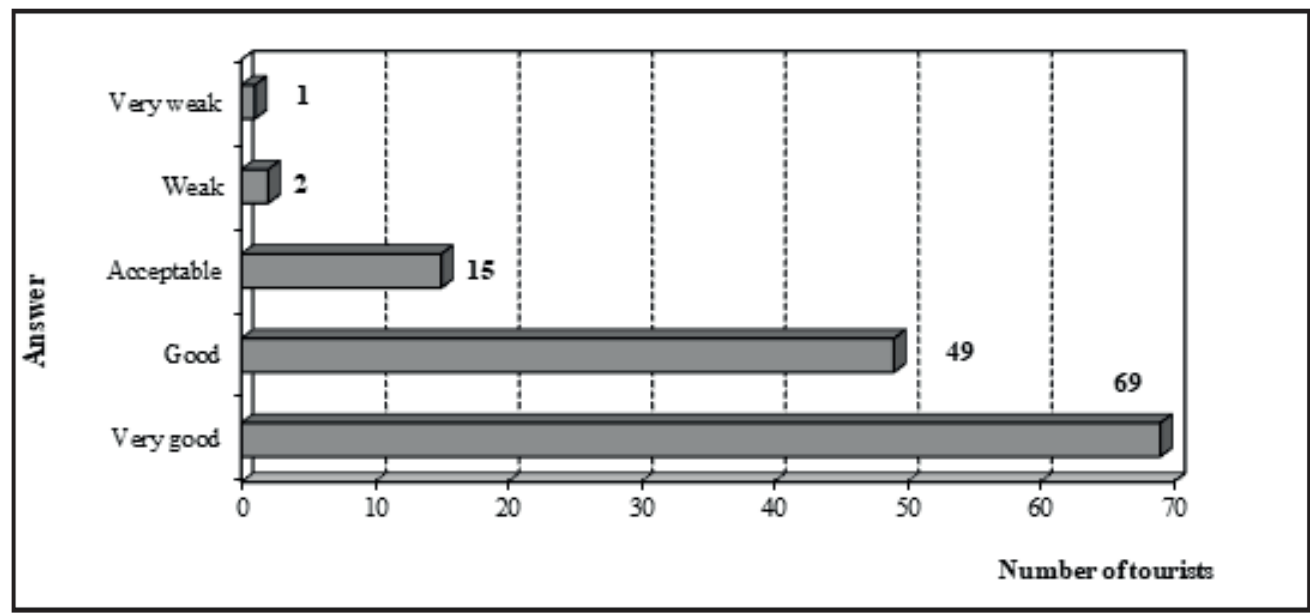

Fig. 11. The perception of accommodation and food services from Bihor spa destination in terms of the quality-price ratio in relation to other targeted tourist destinations (number of cases)

\section{DISCUSSION AND CONCLUSIONS}

Băile Felix - Băile 1 Mai spa destination, through the qualitative and quantitative services offered, is the biggest destination of such kind in Romania, having an accommodation capacity of 8399 places. In this respect, the analysis of tourists' perception regarding the tourist destination image is a strategic component that has to be taken into account in the process of sizing and optimising the local tourism, especially under the umbrella of global pressure to achieve Sustainable Development Goals [43-45].

The results of the present study have shown that this Bihor tourist destination is wellknown among tourists (74\% of respondents had prior experience in this area); they had an affinity for Băile Felix - Băile 1 Mai area (45.6\%), as well as for Oradea (28.7\%) and the mountain area (20.5\%). Tourists were influenced in choosing the holiday destination by tourist promotion actions ( $75.7 \%)$, especially by the ones undertaken online $(32.1 \%)$, and by their relatives/acquaintances' opinion.

In relation to the consumption habits, it was noticed that the majority of subjects travel twice (29\%), three times (27\%) a year, by car/coach (66.9\%), train $(22.1 \%)$, and plane $(11 \%)$. They mainly check into hotel structures (78\%), for at least five days (60\%). The sums of money they are willing to spend on a holiday in the targeted destination range between 500 and 1000 RON (32\% of the respondents), and 1000-2000 RON respectively (31\% of the respondents). At the opposite end are those willing to spend sums under 500 RON (11\% of the respondents) and over $5000 \mathrm{RON}$ (3\% of the respondents).

In this context, in terms of the quality-price ratio, respondents perceive the accommodation and food services in the spa destination related to other targeted tourist destinations as being very good (51\%) and good (36\%).

From the analysis of the ratio of the sum tourists are willing to spend on a holiday, number of nights, frequency of travels and perception of the quality-price ratio regarding accommodation and food services, the tourist's profile emerges: moderate regarding the 
frequency of travels and willingness to spend money, satisfied with the accommodation and food services, and willing to spend as much time as possible in Băile Felix - Băile 1 Mai spa destination (Fig. 12).
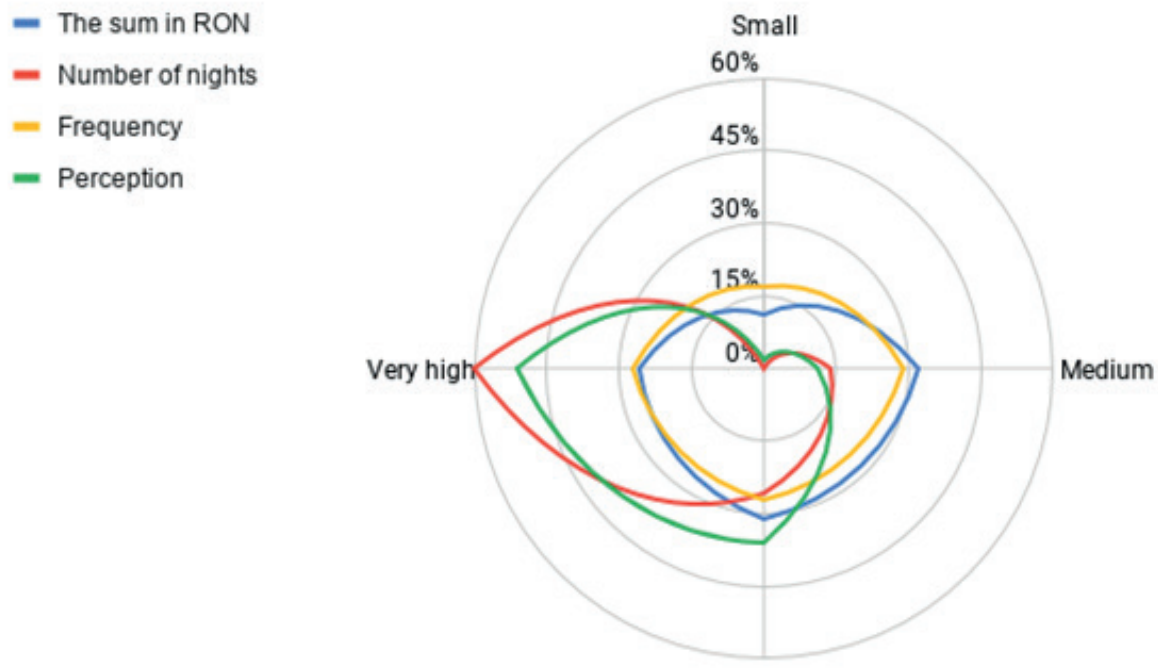

High

Fig. 12. The ratio of the sum tourists are willing to spend on a holiday, number of nights, frequency of travels and perception of the quality-price ratio regarding accommodation and food services

\section{REFERENCES}

[1] Hudson S, Thal K, Cárdenas D, Meng F. Wellness tourism: stress alleviation or indulging healthful habits?. International J Culture Tourism Hospitality Res. 2017;11(1):35-52. https://doi.org/10.1108/IJCTHR-09-2015-0111

[2] Dillette AK, Douglas AC, Andrzejewski C. 2020. Dimensions of holistic wellness as a result of international wellness tourism experiences. Curr Iss Tourism. 2020;1-17. https://doi.org/10.1080/13683500.2020.1746247

[3] Herman GV, Banto N, Caciora T, et al. Tourism in Bihor County, Romania. Trends and Prospects. Folia Geogr. 2020; 62:87-105

[4] Global Wellness Institute, 2018. Global Wellness Tourism Economy: Europe. [Available at: www.globalwellnessinstitute. com] [Accessed on 22 June 2020].

[5] Chen KH, Chang FH, Wu C. Investigating the wellness tourism factors in hot spring hotel customer service. J Contemp Hospital Manag. 2013;25(7):1092-1114. https://doi.org/10.1108/IJCHM-06-2012-0086

[6] Silvestri C, Aquilani B, Ruggieri A. Service quality and customer satisfaction in thermal tourism. TQM J. 2017 29(1):55-81. https://doi.org/10.1108/TQM-06-2015-0089

[7] Chen KH, Chang FH, Liu FY. Wellness Tourism among Seniors in Taiwan: Previous Experience, Service Encounter Expectations, Organizational Characteristics, Employee Characteristics, and Customer Satisfaction. Sustainability. 2015;7(8):10576-10601. https://doi.org/10.3390/su70810576

[8] Zollo A, Simonetti B, Salsano V, Rueda-Armengot C. Promotion and marketing: Marketing strategies, Italy, regional development. Health Wellness Tourism. 2015:63-76). https://doi.org/10.1007/978-3-319-11490-3 5

[9] Kucukusta D, Guillet BD. Measuring spa-goers' preferences: a conjoint analysis approach. Int J Hospital Manag. 2014;41:115-124. https://doi.org/10.1016/j.ijhm.2014.05.008

[10] Luo Y, Lanlung (Luke) C, Kim E, Tang LR, Song SM. Towards quality of life: the effects of the wellness tourism experience. JTravel Tourism Marketing. 2017;35(4):410-424. https://doi.org/10.1080/10548408.2017.1358236

[11] Chen KH, Liu HH, Chang FH. Essential customer service factors and the segmentation of older visitors within wellness tourism based on hot springs hotels. Int J Hospital Manag. 2013;35:122-132. https://doi.org/10.1016/j. ijhm.2013.05.013

[12] Buhaș SD, Stance L. The Relationship between Personality and Physical Activity. Geosport Soc. 2017;7(2):72-77.

[13] Dragoș P, Szabo-Alexi M, Szabo-Alexi P, et al. Investigations concerning the influence of sports trainings carried out in a protected area (Natura 2000 site) on various physiological and biological parameters for athletes. Geosport Soc. 2017;6(1):40-46

[14] De Vos P. European materia medica in historical texts: Longevity of a tradition and implications for future use. $J$ Ethnopharmacology. 2010;132(1):28-47. https://doi.org/10.1016/j.jep.2010.05.035

[15] Khiari I, Mefteh S, Sánchez-Espejo R, et al. Study of traditional Tunisian medina clays used in therapeutic and cosmetic mud-packs. Appl Clay Sci. 2014;101:141-148. https://doi.org/10.1016/j.clay.2014.07.029

[16] Boda I, Timoc C, Bunoiu V. Population dynamics at the spas of Roman Dacia. Case study: the population of Băile Herculane. Studia Antiqua et Archaeologica. 2017;23(1):173-185.

[17] Munteanu C, Dogaru G. Bioclimatologie: bioclimatologie umana [Bioclimatology: human bioclimatology]. Bucharest: Balnear Publishing House; 2020. 
[18] Herman GV, Deac AL, Ciobotaru AM, Andronache IC, Loghin V, Ilie AM. The role of tourism in local economy development. Bihor County Case Study. Urbanism Architecture Constructions. 2017; 8(3):265-274

[19] Herman GV, Peptenatu D, Grama V, Pintilii RD. Tourism and Local Development. Study Case: Băile Felix-Băile 1 Mai Tourism System, Bihor County, Romania. Analele Universității din Oradea. Seria Geografie. 2018;28(1):131-137.

[20] Borović S, Marković I. Utilization and tourism valorisation of geothermal waters in Croatia. Renew Sustain Energy Rev. 2015;44:52-63. https://doi.org/10.1016/j.rser.2014.12.022

[21] Kapczyński A, Szromek AR. Hypotheses concerning the development of Polish spas in the years 1949-2006. Tourism Manag. 2008;29(5):1035-1037. https://doi.org/10.1016/j.tourman.2007.10.001

[22] Joppe M. One country's transformation to spa destination: the case of Canada. J Hospital Tourism Manag. 2010; 17(1):117-126. https://doi.org/10.1375/jhtm.17.1.117

[23] Košić K, Pivac T, Romelić J, Lazić L, Stojanović V. Characteristics of thermal-mineral waters in Backa region (Vojvodina) and their exploitation in spa tourism. Renew Sustain Energy Rev. 2011;15(1):801-807. https://doi.org/10.1016/j. rser.2010.09.004

[24] Drăghici CC, Pintilii RD, Peptenatu D, Comănescu LG, Sirodoev I. The role of SPA tourism in the development of local economies from Romania. Procedia Economics and Finance. 2015;23:1573-1577. https://doi.org/10.1016/ S2212-5671(15)00400-1

[25] Ilie AM, Herman GV, Ciobotaru AM, Grecu A, Radu RA, Visan MC, Giurgia M. The role of tourism in structural dynamics of the economic profile of Sighisoara city. Urbanism Architecture Constructions. 2017;8(4):377-386.

[26] Grecu A, Gruia AK, Marin M, et al. Specificity of Sustainable Structural Dynamics of Local Economy in Romanian Tourist Resorts. Sustainability. 2019;11(24):7155. https://doi.org/10.3390/su11247155

[27] Dwivedi M. Online destination image of India: A consumer based perspective. Int JContemp Hospital Manag. 2019; 21(2):226-232. https://doi.org/10.1108/09596110910935714

[28] Lv X, Mccabe S. Expanding theory of tourists' destination loyalty: The role of sensory impressions. Tourism Manag. 2020;77:104026. https://doi.org/10.1016/j.tourman.2019.104026

[29] Araujo A, Cardoso L, Araujo N, Dias F. Understanding the role of destination imagery in mountain destination choice. Evidence from an exploratory research. European Journal of Tourism Research. 2018; 22:151-165.

[30] Toral SL, Martínez-Torres MR, Gonzalez-Rodriguez MR. Identification of the Unique Attributes of Tourist Destinations from Online Reviews. J Travel Res. 2018;57(7):908-919. https://doi.org/10.1177/0047287517724918

[31] Herman GV, Banto N, Caciora T, Ungureanu M, Furdui S, Garai LD, Grama V. The Perception of Bihor Mountain Tourist Destination from Romania. Geographia Polonica. 2021;94(1), under evaluation.

[32] Bryman A. Social Research Methods, 4th edition. Oxford University Press, USA; 2012.

[33] Chelcea S. Metodologia cercetării sociologice. Metode cantitative și calitative [Methodology of sociological research. Quantitative and qualitative methods]. Editura Economică, Bucharest; 2007. Romanian.

[34] Wendt J, Buhas R, Herman GV. Experience of the Baile-Felix Tourist System (Romania) For the Protection and Promotion of the Grey Seal as a Brend on the Hel Peninsular (Poland). Baltic Region/Baltijskij Region. 2019;11(1):109-16. https:// doi.org/10.5922/2079-8555-2019-1-8

[35] Herman GV, Biriș MS, Ilieș DC. The perception of geography in school and society. Bal J Health Phys Act. 2020;12(spec. iss. 1):112-119. https://doi.org/10.29359/BJHPA.12.Spec.Iss1.13

[36] Herman GV, Grama V, Sonko SM, Boc E, Băican D, Garai LD, Blaga L, Josan I, Caciora T, Gruia KA, Grecu A. Online Information Premise in the Development of Bihor Tourist Destination, Romania. Folia Geographica. 2020; 62(1):21-34.

[37] Herman GV, Ilies DC, Dehoorne O, Ilies A, Sambou A, Caciora T. Emitter and tourist destination in Romania. Balt J Health Phys Act. 2020;12(1):120-38. https://doi.org/10.29359/BJHPA.12.Spec.Iss1.14

[38] National Authority for Tourism. Structurile de primire turistică cu funcţiuni de cazare clasificate, 2019 [Tourist structures with classified accommodation functions, 2019]. [Available at: http://turism.gov.ro/web/autorizare-turism/] [Accessed on 6 Octomber, 2020]. Romanian.

[39] The National Bank of Romania (2019). BNR Course Archive. Retrieved from https://www.cursbnr.ro/arhiva-cursbnr-2019-06-30 [20 April 2021].

[40] National Institute of Statistics (2019). Average monthly earnings. Retrieved from https://insse.ro/cms/ro/tags/ comunicat-castig-salarial?page $=2$ [20 April 2021]

[41] Wendt JA, Chroń M, Jaźwiecka M, Wiskulski T. Differences in the perception and evaluation of tourist attraction of Menorca by its residents and tourists. GeoJ Tourism Geosites. 2016;1(17):21-31.

[42] Wendt JA. Tourism development challenges on the Dead Sea shore. Limnological Rev. 2016;2:105-112. https://doi. org/10.1515/limre-2016-0011

[43] Robert KW, Parris TM, Leiserowitz AA. What is sustainable development? Goals, indicators, values, and practice. Environment: Science and Policy for Sustainable Development. 2005;47(3):8-21. https://doi.org/10.1080/0013915 7.2005.10524444

[44] Lewandowska I, Drzewicki A, Wendt JA. Awareness of the Cittaslow network among students in Olsztyn and Gdańsk cities. Pol J Natur Sci. 2019;34(4):559-573.

[45] Wendt JA, Grama V, Ilieş G, et al. Transport Infrastructure and Political Factors as Determinants of Tourism Development in the Cross-Border Region of Bihor and Maramureş. A Comparative Analysis. Sustainability. 2021;13: 5385. https://doi.org/10.3390/su13105385 